\title{
The Analysis of Influence of the Monetary Policy Carried out by The National Bank of Georgia on the Local Business Entities (Based on the Cases of Development Business)
}

\author{
Giorgi Katamadze
}

\begin{abstract}
The aim of the article is to study the reasons of the business entities crisis caused as a result of the monetary policy carried out by The National Bank of Georgia. The research is conducted by applying the case-study methodology. The research outcomes will have both the theoretical and the practical values. The development business entities crisis analysis from the prospective of actors is undoubtedly a new approach in economic researches. "The presentation was supported by Shota Rustaveli National Science Foundation of Georgia (SRNSFG) [grant number MG-TG-19-228]".
\end{abstract}

Index Terms-Business entities, development business, national bank, regulations, monetary policy.

\section{CONCEPT OF THE PRESENTATION}

\section{A. The Significance of the Research Topic}

Depreciation of the Georgian currency in recent years largely affected the activities of local business entities. In response to the problem, the Georgian National Bank, as a fiscal policy maker body of the country, took all necessary measures to strengthen the currency. However, the negative effects of the measures, such as income loss and financial crisis, gradually reflected on the activity of business entities.

\section{B. The Novelty}

The novelty of the research is the quantitative-qualitative study of the influence of the monetary policy carried out by the National Bank of Georgia on the local business entities, by applying the component analysis of cases of business entities crisis. The methodology of depth interviewing and case study will be applied instead of standard business analysis (applying the financial models).

Foreign scientific researches mainly focus on crisis in enterprises, in particular, E. Altman's [1] works are devoted to the models of bankruptcy, to the state role in crisis management are devoted P. Samuelson's [2], F. Hayek's [3], A. Hansen's [4] and other's works; to the crisis management by applying credit interventions are devoted the works of $\mathbf{J}$. Schumpeter [5], [6] and others.

Despite that plenty of materials are devoted to the topic, only few of them focus on research of the company cases of the same type, aiming to reveal the factors of crisis caused by

Manuscript received June 20, 2019; revised September 11, 2019. The presentation was supported by Shota Rustaveli National Science Foundation of Georgia (SRNSFG) [grant number MG-TG-19-228].

Giorgi Katamadze is with Batumi Shota Rustaveli State University, Georgia (e-mail: katamadze.g@gmail.com). the monetary policy. This interdisciplinary approach analyzes the entity crisis from the prospective of the processes, institutions and actors, instead of applying the statistical or financial models.

Being a novelty for the Georgian academic community, I believe the approach will become a kind of a model for similar researches being carried out in other countries.

\section{The Objectives of the Research}

Overview of the literature on crisis theory and practice, the regulations of the National Bank related to the monetary policy and the individual analysis of the cases of the development business entities.

\section{Methodology of the Research}

The case-study method - the study of a certain case of business entity crisis, which provides an opportunity of conducting a depth analysis of the situation.

The comparative method will be applied for comparative analysis of data existing in the similar categories, during one and the same period of time, in order to define the tendencies of a certain component. The analysis of the official documentation, which includes the analysis and classification of the official data, documentation, decisions provided by the state departments.

\section{EXPECTED OUTCOMES, ITS IMPACT AND APPLICABILITY}

The study of crisis by applying the interdisciplinary methodology will facilitate the spreading of new approaches and materials. The given scientific research will have clear theoretical and practical outcomes, which will help the researches of the similar business entities crisis. This might be accepted as a theoretical and practical outcome for the effective development of the local and international companies.

The research outcomes will be useful for the business entities, as well as for governmental and non-governmental organizations that work on crisis prevention. The outcomes will also help the companies in business strategic planning considering the ongoing and future regulations of the monetary policy.

The main objective of the monetary policy of the National Bank of Georgia is to maintain price stability. Price stability implies the existence of a moderate and predictable rate of inflation, which is a necessary precondition for long run economic growth. The more effective are the monetary policy instruments, the lower is the social cost of maintaining price stability. 
Consequently, the National Bank of Georgia permanently works to develop/improve monetary policy instruments and increase the efficiency of its monetary transmission mechanism.

In the first quarter of 2019 the annual growth of the credit portfolio reduced and in March amounted to $15 \%$ excluding the exchange rate effect. In March, compared with December, the annual volume of loans provided to individuals reduced to $4.5 \%$ and totaled $14.4 \%$; the annual increase of credits granted to legal entities also reduced to $0.8 \%$ and totaled $15.7 \%$ [7].

In terms of currency, it's noticeable, that the loans provided both in national and foreign currencies, equally contributed to the growth of credit portfolio in the first quarter of 2019; in March the annual credit portfolio denominated in foreign currency increased by $13.6 \%$ and by $16.8 \%$ in Georgian Lari (GEL) [7].

Interest rates in the interbank foreign exchange market vary depending on the policy carried out by the National Bank [7]. According to financial experts the new credit regulations mostly were expected to have adverse impacts on development business, although various recommendations were not considered by the government and the new credit regulations were adopted.

In recent years, the development (construction) business has been steadily growing in Georgia. The residential constructions are mostly carried out in Tbilisi and Batumi cities. Therefore, according to the report of The Transparency International Georgia on "Construction Sector in Georgia 2018": In 2014-2017, the Georgian economy annually was growing by $3.8 \%$, while the annual growth of the construction sector for the same period was 3 times more $-12 \%$.

The construction sector decreased dramatically (by 10.1\%) in 2013. After 2013, another reduction (by $0.3 \%$ ) of the construction sector was monitored in the first half of 2018 as a result of an increased $\mathrm{K} 2$ coefficient and decreased number of permits [8].

Main statistical data about construction sector in Georgia, 2014-2019 years can be found in the Fig. 1:

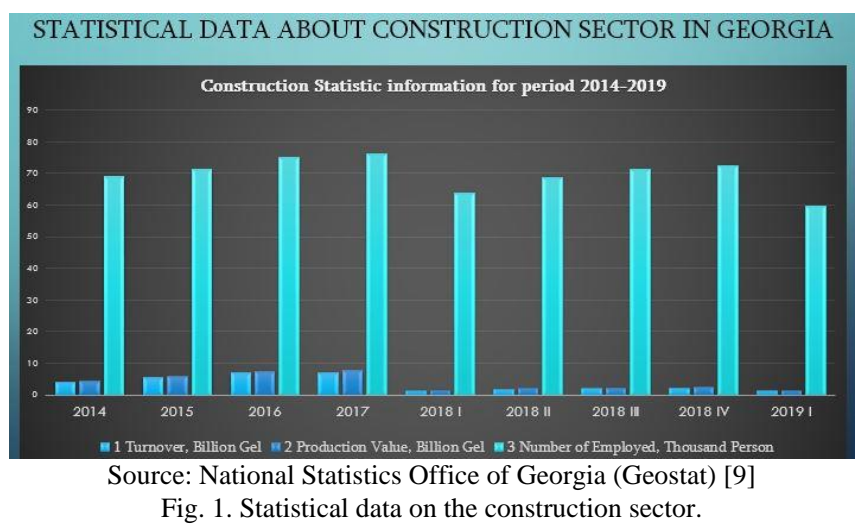

As for the K2 coefficient - the construction intensity coefficient, the major acts regulating the construction sector are: The Decree N41 of January 28, 2016 of the Government of Georgia on Approving Technical Regulations for the Safety Rules for Buildings [10] - This Technical Rule regulates the planning, fire safety, provision of exit facilities and other requirements for the design, construction and use of buildings.

Law of Georgia on Spatial Development and Basis for City-building, Product Safety and Free Circulation Code, Law of Georgia on Construction Activity, Law of Georgia on Architectural Activity, The Decree of the President of Georgia. Decree N660 of the President of Georgia of November 24, 2007 [11] on Adoption of the Rule of Approval of Legalization of Unlawful and/or Illegal Constructions or Parts of Constructions by the Issuing Authority of the Construction Permit, Decisions of the Government of Georgia. The Decree N57 of March 24, 2009 of the Government of Georgia on Regulation of Permission for Construction and Permit Conditions [12], The Decree N261 of August 25, 2010 of the Government of Georgia on Approval of the Law for Establishing the Boundaries for the Land Plots of the Commonwealth of the Ownership Members [13], The Decree N50 of March 7, 2013 of the Government of Georgia on Access of Operation of the Technical Regulations of Foreign Countries in Georgia [14], Recognition of Documents, Accrediting Products without Conformity Assessment Procedures and Free Access of Foreign Products to Georgian Markets Assigned to Regulated Areas, The Decree N59 of January 15, 2014 of the Government of Georgia on Use of Urban Areas and Main Provisions of Approval of Plant Regulation [15], The Decree N52 of January 14, 2014 of the Government of Georgia on Validity of Operation and Recognition of Technical Regulations of Construction in Georgia [16], The Decree N41 of January 28, 2016 of the Government of Georgia on Approving Technical Regulations for the Safety Rules for Buildings - This Technical Rule regulates the planning, fire safety, provision of exit facilities and other requirements for the design, construction and use of buildings [17].

All these regulations contributed to the legal regulation of the construction business and improvement of the construction quality. However, each amendment to the legislation and adoption of a new regulation necessitates adaptation of particular directions of the business to these normative acts, that, in its own way, is connected to the change of business strategies and extra expenses.

The decisions on state monetary policy and especially, the amendments to the credit policy, deserve special attention, having specific importance for the economic processes.

Within the frames of this research, one of the Georgia-based construction companies was selected; the company has got some constructions in Batumi and Tbilisi, in those cities officially highlighted by the great number of constructions and real estate sales. The company selection criteria included:

1) the area of activity of the company: Batumi and Tbilisi;

2) its working experience: more than 5 years;

3) its sales volume: on average 35-40.000 sq.m of residential space annually;

4) the company's sales strategy oriented on resident purchasers/buyers.

The results of this research demonstrate that the company activities are mainly impacted by adoption of any new regulation. As it was highlighted in the interview by one of the companies, it's business state was significantly 
influenced by one of the adopted regulations, in particular, the Decree N41 of January 28, 2016 of the Government of Georgia on Approving Technical Regulations for the Safety Rules for Buildings - This Technical Rule regulates the planning, fire safety, provision of exit facilities and other requirements for the design, construction and use of buildings [17].

The implementation of the technical guidelines of the regulation surged the real estate net costs, since meeting of its requirements and standards is connected to extra expenses. The increased net costs raised the prices of apartments and partially affected the sales.

Since the objective of the paper was to study the influences caused by the regulations of the National Bank of Georgia, we also have researched the impacts of some other regulations, in particular: The Decree N4/04 of the President of the National Bank of Georgia of January 13, 2017 on "determination of rules of issuing loans up to GEL 100.000 by commercial banks" [18], The Decree N5/04 of January 18, 2017 on "determination of rules of issuing bank credits up to GEL 100.000 by commercial banks" [19], The Decree N281/04 of the President of the National Bank of Georgia of December 24, 2018 on "adoption of a provision of crediting a physical person" [20] and The Decree N7/04 of the President of the National Bank of Georgia of January 18, 2019 on "determination of rules of issuing bank credits up to GEL 200.000 by commercial banks" [21].

By the information provided by the national bank of Georgia for the period of time from 2017/07 until 2019/07, the loans issued by Commercial Banks, Stock can be found in the Fig. 2:

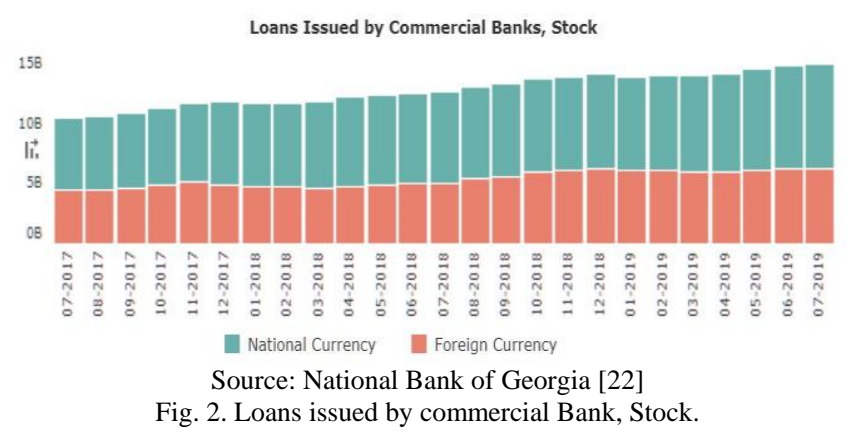

The research outcomes showed that reduction of sales of the companies being studied within the frames of this research, from 2016 up to the present moment rages within $25-32 \%$, in particular, such decrease was first monitored in 2017 and a sharp downfall after January of 2019. It also should be noticed that a great share of total sales was represented by apartments purchased on a real estate loan.

As a result of enforcement of the new regulation (which requires a detailed study of a borrower's incomes and the maintenance of a strictly defined ratio between such incomes and the monthly payment in line with schedule) the physical persons became limited in undertaking credits. As well as the maximal term of loans reduced to 15 years (in the past such term was 20 years). Since the credit volume is defined in accordance with the credit term, the term reduction resulted in the credit volume decrease to $25 \%$.

According to the data provided by the National Bank, the number of short-term mortgage loans in foreign currency has been decreased from November 2018; the number of such loans with 1 to 2 -years-term have been increased and with 2-5-years-term - decreased. The mortgages with the term 5 to 10 years, as well as loans lasting more than 10 years are also reduced (National Bank of Georgia Report 2019).

As for the loans in national currency (GEL): the number of such loans with 1 to 2-years-term steadily decreases; there is slight reduction in the number of loan with the term 2 to 5 years; The mortgages with the term 5 to 10 years, as well as longer than 10 years have been increased (National Bank of Georgia Report 2019).

\section{CONCLUSION}

A complex analysis of the abovementioned data enables us to summarize that there is a decreasing trend of the loans in foreign currency with the term longer than 2 years and an increasing trend of the loans in national currency with the same period of time. It's impossible to say definitely if the new crediting regulations initiated by the National Bank have influenced the number of credits in different currency, because the foreign currency fluctuations (and in recent years the exchange rates are increasing steadily) also impact the crediting policy.

Within the frames of the given research, it's possible to conclude the following:

1. According to the data of the National Bank of Georgia, changes of the crediting regulations did not influence the volume/number of short-term mortgage loans; therefore, provided that major part of apartments (under construction) were to be purchased by the residents on mortgage loans, the regulation did not have much effect on the development business.

2. The research has shown that in banking sphere the new crediting regulations impacted those consumer loans secured by the immovable property - the volume/number of credits/loans are reduced in recent period. But it should be noticed, that the purpose of such loans is not directly connected to the sale-purchase operations of the immovable property, therefore, the reduction itself has not affected the development business.

3 . The research proved that a substantial impact on development business was made by the Decree N41 of January 28, 2016 of the Government of Georgia on Approving Technical Regulations for the Safety Rules for Buildings - This Technical Rule regulates the planning, fire safety, provision of exit facilities and other requirements for the design, construction and use of buildings; under the regulation, the construction companies are required to ensure meeting all the modern safety and other technical standards; this is linked to extra costs for the companies. Such requirements did not exist in the past, therefore considering the extra costs, the primary costs on the immovable property increased. In order, the development companies to maintain their planned profit margin, the companies raised the prices on built apartments and raised prices affected the overall demand on property.

4. The development business in Georgia is improving. Despite the fact that new regulations raise the costs of the 
construction companies and directly influences the prices on real estate, such changes of regulations facilitate the perfection of the city infrastructure in line with the modern standards providing safety and appropriate conditions for living.

\section{CONFLICT OF INTEREST}

The author declares no conflict of interest.

\section{AUTHOR CONTRIBUTIONS}

The work has only one author, therefore all the tasks related to the work, among them conducting the research, analyzing the data, writing the paper and approval of the final version were performed by Giorgi KATAMADZE.

\section{REFERENCES}

[1] A. Edward, Financial Ratios, Discriminant Analysis and the Prediction of Corporate Bankruptcy, 1868.

[2] A. S. Paul, "Maximum principles in analytical economics," Massachusetts Institute of Technology, Cambridge, Massachusetts Nobel Memorial Lecture, December 11, 1970.

[3] A. H. Friedrich, Unemployment and Monetary Policy: Government as Generator of the "Business Cycle", 1979.

[4] H. Alvin, "Economic progress and declining population growth," American Economic Review, no. 29, March 1939.

[5] A. S. Joseph, The Theory of Economic Development an Inquiry into Profits, Capital, Credit, Interest, and the Business Cycle, Routledge, 2017.

[6] J. A. Schumpeter, Econometrica, 1933.

[7] National Bank of Georgia, Monetary Policy Report, May 2019, pp. 21-23.

[8] B. Namchavadze and L. Natroshvili, The Report of the Transparency International Georgia: Construction Sector in Georgia, 09 January, 2019.

[9] National Statistics Office of Georgia. (2019, Sept.). [Online]. Available: https://www.geostat.ge/ka/modules/categories/80/mshenebloba

[10] The Decree N41 of January 28, 2016 of the Government of Georgia on Approving Technical Regulations for the Safety Rules for Buildings.

[11] The Decree N660 of the President of Georgia of November 24, 2007.
[12] The Decree N57 of March 24, 2009 of the Government of Georgia on Regulation of Permission for Construction and Permit Conditions.

[13] The Decree N261 of August 25, 2010 of the Government of Georgia on Approval of the Law for Establishing the Boundaries for the Land Plots of the Commonwealth of the Ownership Members.

[14] The Decree N50 of March 7, 2013 of the Government of Georgia on Access of Operation of the Technical Regulations of Foreign Countries in Georgia.

[15] The Decree N59 of January 15, 2014 of the Government of Georgia on Use of Urban Areas and Main Provisions of Approval of Plant Regulation.

[16] The Decree N52 of January 14, 2014 of the Government of Georgia on Validity of Operation and Recognition of Technical Regulations of Construction in Georgia.

[17] The Decree N41 of January 28, 2016 of the Government of Georgia on Approving Technical Regulations for the Safety Rules for Buildings.

[18] The Decree N4/04 of the President of the National Bank of Georgia of January 13, 2017 on "determination of rules of issuing loans up to GEL 100.000 by commercial banks".

[19] The Decree N5/04 of January 18, 2017 on "determination of rules of issuing bank credits up to GEL 100.000 by commercial banks".

[20] The Decree N281/04 of the President of the National Bank of Georgia of December 24, 2018 on "adoption of a provision of crediting a physical person".

[21] The Decree N7/04 of the President of the National Bank of Georgia of January 18, 2019 on "determination of rules of issuing bank credits up to GEL 200.000 by commercial banks.

[22] National Bank of Georgia, Current Condition of Commercial Banks Loan Portfolio, Aug. 2019.

Copyright (C) 2020 by the authors. This is an open access article distributed under the Creative Commons Attribution License which permits unrestricted use, distribution, and reproduction in any medium, provided the original work is properly cited (CC BY 4.0).

Giorgi Katamadze was born on 26, December, 1984 in Batumi, Georgia Giorgi Katamadze got his $\mathrm{PhD}$ in business administration at Batumi Shota Rustaveli State University, Georgia. He is an author of several publications about Business Crisis and Preventive Anti-Crisis strategies. Dr. Giorgi Katamadze has been working in banking sector since 2007 year; at the present moment he works at JSC Ziraat Bank Georgia Batumi Sub-Branch as a credit manager. He is also an invited lecturer at Batumi Shota Rustaveli State University, Georgia. 